\title{
Merging Fact, Fiction and Myth: Reading TD Ramakrishnan's Sugandhi Enna Aandaal Devanayaki as a Historiographic Metafiction
}

Subin Varghese

Assistant Professor

Department of English

Deva Matha College

Kuravilangad, Kerala, India

subindmc@gmail.com

Abstract

TD Ramakrishnan's novel Sugandhi Enna Aandaal Devanayaki is a mixture of the mythological, metaphysical and historical into a fictional space which transcends the boundaries of nation. The novel is a quest for retelling the historical trauma of Sreelanka. In the search for Sugandhi a Tamil liberation activist, the narrator stumbles upon the mythical Sugandhi from the folklore, creating tension between faction and reality. In the search for the mythical Sugandhi Ramakrishnan uses 'SusinaSupina' and arrives at Devanayaki belonging to $7^{\text {th }}$ century AD Pallava Dynasty. As fact, fiction and myth blur into the contemporary social space, the myth of Devanayaki merges with Rajani Thirinagame creating the notion of the alternate history from a female perspective. In the novel History blurs into myth, reality into fiction, contemporary into past, individual into society and body into spirit.TD Ramakrishnan deconstructs the millennium old Tamil- Sinhalese political history using the alternate history from mythology and folklore. This paper is an attempt to read the novel Sugandhi Enna AandaalDevanayaki as a Historiographic metafiction.

Keywords: Myth, Reality, History, Fiction, Historiographic metafiction 
TD Ramakrishnan's novel Sugandhi Enna AandaalDevanayaki is a mixture of the mythological, metaphysical and historical into a fictional space which transcends the boundaries of nation. The novel tells the traumatic experiences of Srilankan people. In the search for Sugandhi, a Tamil liberation activist, the narrator stumbles upon the mythical Sugandhi from the folklore, creating tension between fiction and reality. In the search for the mythical Sugandhi Ramakrishnan uses 'SusinaSupina' and arrives at Devanayaki belonging to $7^{\text {th }}$ century AD Pallava Dynasty. As fact, fiction and myth blur into the contemporary social space, the myth of Devanayaki merges with Rajani Thirinagame creating the notion of the alternate history from a female perspective. In the novel history blurs into myth, reality into fiction, contemporary into past, individual into society and body into spirit.TD Ramakrishnan deconstructs the millennium old Tamil- Sinhalese political history using the alternate history from mythology and folklore.

Peter Jeevanantham, one of the central characters in the novel is in search for Sugandhi, his lover who was a member of the LTTE group. He goes to Sreelanka for searching materials for his movie "The woman Bahind the Fall of the Tigers". The novel spins between the life of Rajini Thiranagama who was a Sreelankan activist killed by the LTTE, Sugandhi the lover of Peter Jeevantham and Sugandhi, a mythological character. The novel shows a number of political and historical events which questions the political forces and the government. History, mythology and fiction are banded together to make the readers dodge between reality, fiction and history.

Rajini Thiranagama, a vibrant member of the LTTE, was a woman of calibre and fire who raised her voice against the undemocratic deeds and the thraldom of the movement. She came to the Iyakkamm with the feeling that freedom could be achieved in one day through the activities of the group but was disillusioned by the movement. She has raised her voice against the LTTE in the book she wrote The Broken Palmyra. In the book she writes "Men in 
battle garb, whether they come with swords or guns, on a horse or in armed cars, the price of conquest seems heightened by the violation of women" (22). What she experienced in Iyakkam was the patriarchal power structure which never accepted the voices of women. Women were exploited by the government as well as by Iyakkam.

Another powerful female character in the novel is Devanayaki, a mythological figure lived in tenth century AD. She was a learned woman who had studied Arthashasthra. Devanayaki wanted to attain moksha through happiness both of mind and body. But she also was discarded by the patriarchal kings and was treated as merely a body. She later became the part of Arya Devi myth and attained nirvana. The mythology of Devanayaki tells that whenever a woman is in trouble, she will come to rescue the woman who is hurt. Thus, Rajani Thiranagama and Sugandhi are the incarnation of Devanayaki. Devanayaki has become the symbol of resistance of women.

Kulbir Kaur in the article titled "Gendered resistance meshes myth" says "the use of myth, memory and history also interrogates the complex modern world and its various dimensions. The power camps of every type and nature are just machines to repress and crush women. Wearing the mask of progress and development, fascist forces control the masses, reducing them to puppets."

T.D Ramakrishnan uses the fictional strategy which juxtaposes a private personal history in a public record in order to expose the gaps in the public records attempt to encapsulate the historical past. Sugandhi Enna Aandal Devanayaki attempts an interrogation of public or official history by incorporating and comparing by their placement, the text of official history and those of individuals endeavoring to survive the political situation of war. The political situation of Srilanka is deconstructed and reconstructed through the use of myth, fiction and folklore in the novel Sugandhi Enna Aandal Devanayaki. The novel uses many real-life characterization and situations which blur the gap between fact and fiction. 
The novel opens with Peter Jeevanandham and his colleagues endeavor in the making of the film titled 'Women Behind the Fall of Tigers'. The script was to be written by Peter since he had direct experience with the political issues of Srilanka and the Tamil tigers. Peter searches for Sugandhi to do the role of Rajani and he comes to know about the tortures she faced. The history of Srilanka is delineated through the eyes of Peter and his experience.

We planned to portray the theme how the anti-democratic strategies of revolutionary institutions cause its own down fall and how women become a cause of the downfall. That is why Christy instilled me the responsibility of writing the script of the film since I had direct experience of being with Tamil tigers at the time of the golden days of Prabhakaran .(10)

When the novel proceeds Peter becomes a character within the novel, shortening the distance between fact and fiction.

By quoting the song 'No more tears sister' the novel is dedicated to Rajani Thiranagama. T.D Ramakrishnan uses the history of the character Rajani to create the character Sugandhi. The historical facts are sabotaged in the novel to show the fallacious nature of the constructed official history by those who are in power. The novel portrays the character Sugandhi mixing reality, fiction, myth and folklore.

It was my unlucky childhood that made me a freedom fighter when I grew up. Like several other women revolutionary I was not drag into this kidnapping or threatening the family members. I chose this like myself. But I was wrong in understanding the ways of this institution. (19)

The novel also describes the atrocities and tortures that Sugandhi has undergone. It gives an alternative rendering of history from a female perspective. The novel even though written by a male emphasises the role of women in history. Sugandhi, Devanayaki, Meenakshi Rajarathinam, Juliet, Gayathri Perera are the main characters in the novel who are 
determined and stood strong in the midst of crisis. These women portray self-will and courage and are specimens of their types. The novel also portrays the patriarchal and fascist ways of LTTE. Sugandhi was shot dead by the LTTE for criticizing the patriarchal and fascist ways of the movement.

The novel mixes both historical and real-life characters to blur the gap between history and fiction. Thamizholi alias Thamizhini, leader of Women LTTE who exposed the brutality of the movement in her memoir is depicted as Thamizholi in the novel. One of the real life characters brought in the novel is Prabhakaran who appears in the novel in the form of an interview with Sugandhi in the chapter titled Last meeting. The meeting called 'Who was Rajani Thiranagama?' is mentioned in the novel. A chapter is devoted to the album 'No more Tears Sister" in page 89 . There is reference to Andal belonging to $8^{\text {th }}$ century AD. These real-life characters are suggestive of the merging of facts and fiction. What we find in the novel is the subversion of the official history which is told from a very different perspective to question the authority of the 'original'.

Sugandhi Enna Andal Devanayaki uses myths in order to foreground the similarity between historical facts and mythological narratives which inform a past culture. The mythological signification in the novel examines the ideological urge to naturalize lies behind the ideal world created by historiography. The use of mythical figures Aandal and Devanayaki is an example of the mythological signification. Andal is the only female Alvar among the twelve Alvars. She lived in the first half of the eighth century who is known for her unwavering devotion to Lord Vishnu. Sachidhanandhan a Malayalam poet presented Andal as a beautiful lady who celebrates love in his poem "Andal PranayathepattySamsarikunnu". T.D. Ramakrishnan also uses the historical figure of Devanayaki who belong to KanthalloorPallava dynasty. The mixing up of Andal and Devanayaki in the character Sugandhi merges mythology and history in the contemporary 
world. The title of the novel Sugandhi Enna Andal Devanayaki means Sugandhi alias Andal Devanayaki.

The chapters titled Devanayakinkathai portrays the life of Devanayaki from mythology. It talks of her life at Kanthalloor, Thanjavoor (Kantha Mahadevi) and her story ends when she walks towards this sky with one leg in Sigiria and the other leg in SreePadhamala. The new era of the Andal is about tragedies or the repetition of tragedy. T.D Ramakrishnan uses the myth of Devanayaki in the current social life of Srilanka to portray the social and cultural change and the revolution in Srilanka. As the tale of Tamil Sinhalese strike unfolds its historical dimensions, the personal and mythical enter the frame work of the story to reveal the constructive nature of myth and history. In the words of Meena T. Pillai "the quest for the modern Tamil liberal activist Sugandhi in the contemporary landscape of Srilankan trauma and loss in its self fueled by the tails of the mythical Sugandhi, has archetypal ancestor from a folkloric past, creating a throbbing tension between fiction and reality" (2).

Barthes in his work Historical Discourse refers to text "where the protagonist of the language-act is the same person as the protagonist of the historical event-where in short, the actor turns historian" (149). The novel uses a historian to narrate the incidents of the story. Peter, who is given the character of historian, is one of the major participants in the events. He tells history through his own memory and experiences by decoding the mysteries around him. Peter is presented as a script writer of the film "Women Behind the Fall of Tigers". He says "we are moving forward on the basis of what we have read, heard an experienced" (22). Peter picks up the shred and fragments of events as he experiences it directly and indirectly. T.D Ramakrishnan constructed a historian who presents events in a fragmentary nature, is suggestive of the suspension of the official version of traditional historiography. 
The use of multiple narrators can be seen in the narration of mythical story 'DevanayakinKathai' which is told by Meenakshi Rajarathinam. The reference to 'Susana Supina', an archeological document from where the story of Devanayaki is found also suggests multiple narration. As a historiographic metafiction, the novel attempts to imaginatively recover the past and uses fiction and historiography in order to present an alternate version which revitalizes histories relevance to the present. 


\section{Works Cited}

Barthes, Roland. 1970."Historical Discourse”. Introduction to Structuralism. Ed. Michael Lane. New York: Basic.

Hutcheon, Linda. 1988. "Historiographic Metafiction: The Pasttime of Past Time”. A Poetics of Postmodernism: History, Theory, Fiction. London: Routledge.

Kaur, Kalbir. "Gendered resistance and meshes myth". The Asian Age: 30 September,2018.

Lukacs, Georg.1962. The Historical Novel.London: Routledge

Mink, Louis.2001. "Narrative Form as Cognitive Instrument". The History and narrative Reader. Ed. Geoffrey Roberts. London: Routledge.

Pillai, Meena T.2015. "Mixing Myth and Memory”. The Hindu: Friday Review. 9 July.

Ramakrishnan, T. D. 2014. Sugandi Enna Andal Devanayaki. Kottayam: DC Books.

White, Heyden. 1984."The Question of Narrative in Contemporary Historical Theory”. History and Theory. 23:1. 